
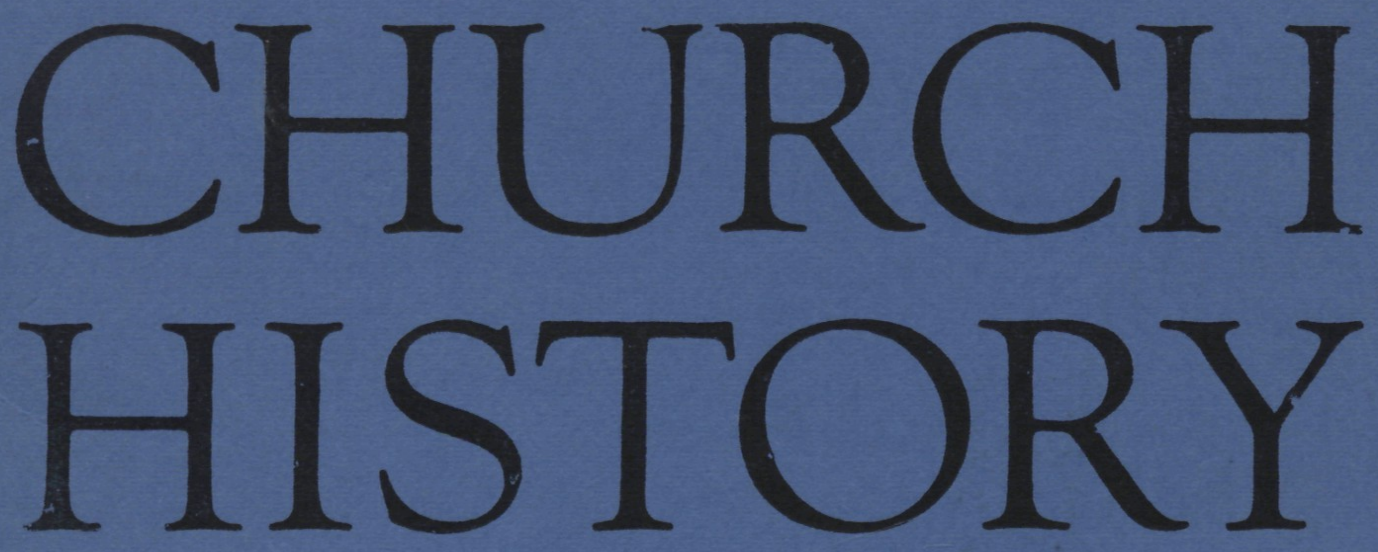

MARCH, 1966

An Essay on the Development of Christian Doctrine Jaroslav Pelikan Sources of Origen's Doctrine of Freedom B. Darrell Jackson

Concilium Generale and Studium Generale: The Transformation of Doctrinal Regulation in the Middle Ages

Peter R. McKeon

Relationships of the Brethren with the Mennonites and Quakers, 1708-1865 Donald F. Durnbaugh Jonathan Edwards and the Theology of the Sixth Way

Robert C. Whittemore

The Moravian Missionaries and the Labrador

Eskimos in the Eighteenth Century William H. Whiteley

Christian Socialism and the First Church of Humanity

Charles Crowe

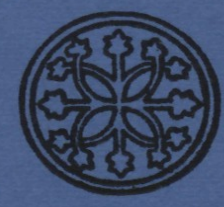

Published by

THE AMERICAN SOCIETY OF CHURCH HISTORY 
Founded By Philip Schaff, 1888: Reorganized, 1906; Incorporated By ACt Of The Legislature of New YORK, 1916

John R. von Rohr ................ President

Richard M. Cameron .. Vice President James H. Smylie ................ Secretary

(Union Theological Seminary, Richmond, $\mathrm{Va}$.)
FOR 1966

Stuart C. Henry ........ Asst. Secretary Guy S. Klett Robert M. Grant Martin E. Marty Treasurer Jerald C. Brauer Editors

\section{VOTING MEMBERS OF THE COUNCIL}

Harold J. Grimm

Lefferts A. Loetscher

Albert C. Outler

Jaroslav Pelikan
Heiko A. Oberman

Wilbur K. Jordan

Elwyn A. Smith

John Tracy Ellis

\section{OTHER MEMBERS OF THE COUNCIL}

Winfred E. Garrison

Frederick W. Loetscher

John T. McNeill

Wilhelm Pauck

Charles Lyttle

Roland H. Bainton

E. R. Hardy, Jr.

Percy V. Norwood

Kenneth S. Latourette

Matthew Spinka

Cyril C. Richardson

Ernest G. Schweibert

Jerald C. Brauer

Winthrop S. Hudson

Massey H. Shepherd

James Hastings Nichols

Ray C. Petry

Sandford Fleming

Sidney E. Mead

Carl E. Schneider

Leonard J. Trinterud

Quirinus Breen

H. Shelton Smith

George H. Williams

Robert T. Handy

Subscription prices are five dollars a year, one dollar and a half for single copies. Twenty-five cents a year should be added for foreign countries. Remittances should be made to the order of the American Society of Church History. Subscriptions, renewals, changes of address, claims for missing numbers, orders for single copies of current or back issues should be addressed to Guy S. Klett, 321 Mill Road, Oreland, Pennsylvania. Claims for missing numbers will be honored without charge if made within two months following the regular month of publication.

Manuscripts and books for review should be sent to the editorial office, Swift Hall, University of Chicago, Chicago 37, Illinois.

Microfilm reproductions of the American Society of Church History Papers, series one and two, and of Church History, volumes I-XVII (1932-1948) are available at cost ( $\$ 22$ and $\$ 39$, respectively, plus transportation) from the ATLA Board of Microtext. Orders should be sent to Raymond P. Morris, Library of the Yale Divinity School, 409 Prospect Street, New Haven 11, Connecticut, as well as inquiries as to microfilm portions, Xerox copies.

Microfilm reproductions of Church History beginning with Volume XVIII are available to subscribers and to members of the Society from University Microfilms, 313 North First Street, Ann Arbor, Michigan.

A cumulative Index of both series of Papers and of Church History through volume XXX (1961) is available at two dollars a copy from Guy S. Klett, 321 Mill Road, Oreland, Pennsylvania.

Publication office is Berne, Indiana 46711

Second-class postage paid at Berne, Indiana 46711.

Send change of address and Forms 3579 to 321 Mill Road, Oreland, Pennsylvania 19075. 


\section{CHURCH HISTORY}

Edited by

Robert M. Grant, Martin E. Marty, Jerald C. Brauer

with the cooperation of

R. Pierce Beaver (Divinity School, University of Chicago)

ROBERT T. HANDY (Union Theological Seminary)

E. R. HARDY, JR. (Berkeley Divinity School)

Winthrop S. Hudson (ColgateRochester Divinity School)
James H. Nichols (Princeton Theological Seminary)

Jaroslav Pelikan (Divinity School, Yale University)

RAy C. Petry (Divinity School, Duke University)

Leonard J. Trinterud (San Francisco Theological Seminary)

George H. Williams (Divinity School, Harvard University)

\begin{tabular}{lll}
\hline VOL. XXXV & MARCH, 1966 & No. 1 \\
\hline
\end{tabular}

\section{TABLE OF CONTENTS}

An Essay on the Development of Christian Doctrine

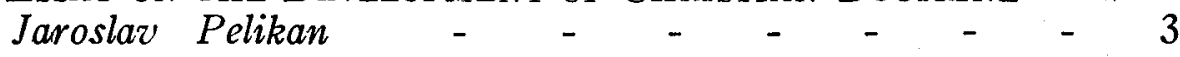

Sources of Origen's Doctrine of Freedom

B. Darrell Jackson - $\quad$ - $\quad$ - $\quad$ - $\quad$ - $\quad$ - $\quad$ - 13

Concilium Generale And Studium Generale: The

Transformation of Doctrinal Regulation in the

Middle Ages

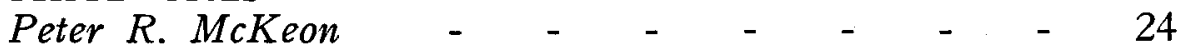

Relationships of the Brethren with the Mennonites AND QUAKERS, 1708-1865

Donald F. Durnbaugh

Jonathan Edwards and the Theology of the Sixth Way

Robert C. Whittemore -

The Moravian Missionaries and the Labrador Eskimos

in the Eighteenth Century

William H. Whiteley -

Christian Socialism and the First Church of Humanity

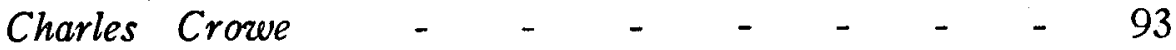




\section{CONTENTS}

\section{Book Reviews}

Dodds, E. R. : Pagan and Christian in an Age of Anxiety .. William R. Schoedel Kelly, J. N. D.: The Athanasian Creed D. Larrimore Holland TIERnEy, Brian: The Crisis of Church and State 1050-1300 ....Allen Cabaniss Adam, PaUl: La vie paroissiale en France an XIV siècle .... Richard Luma f Watanabe, Morimichi: The Political Ideas of Nicholas of Cusa

Richard Luman

Fabian, EкKенart: Die Enstehung des schmalkaldischen Bundes und seiner Verfassung 1524/29-1531/35 Lewis Spitz

Buck, Hermann: Die Anfänge der Konstanzer Reformationsprozesse, Osterreich, Eidgenossenschaft und Schmalkaldischer Bund $1510 / 22-1531$

Lewis Spitz

FrIedmanN, RoBert: Die Schriften der Huterischen Täufergemeinschaften: Gesamtkatalog ihrer Manuskriptbücher, ihrer Schreiber und ihrer Literatur, 1529-1667 ........... Harold J Grimm

Linder, Robert Dean : The Political Ideas of Pierre Viret .... Harold J. Grimm Hunt, George L. ANd MCNeill, John T. (eds.): Calvinism and the Political Order Robert M. Kingdon

D'Etaples, Jacques LefeVRe: Epristres et Evangiles pour les Ciquante \& Deux Sepmaines de l'An; Monter, W. William:

Studies in Genevan Government (1536-1605) Joseph Haroutunian

Thompson, Craig R.: The Colloquies of Erasmus L. J. Trinterud

New, John F. H.: Anglican and Puritan: The Basis of their Opposition $1558-1640$ George Drake

Ware, Timothy: Eustratios Argenti N. Zernov

Akers, Charles W.: Called unto Liberty: A Life of Jonathan Mayhew John Opie

Ellis, John Tracy: Catholics in Colonial America James H. Smylie

Weber, Francis J.: California's Reluctant Prelate; Documents of California Catholic History (1784-1963) ........... John Bernard McGloin

DEDEREN, RAOUL: Un reformateur catholique au $X I X^{\mathbf{e}}$ siecle: Eugene Michaud James D. Nelson

Albright, Raymond W.: A History of the Protestant Episcopal Church Nelson R. Burr

Maring, Norman H.: Baptists in New Jersey: A Study in Transition Hugh Wamble

Jamison, Wallace N.: Religion in New Jersey: A Brief History Norman H. Maring

Levine, LaWrence W.: Defender of the Faith.

William Jennings Bryan: The Last Decade 1915-1925 John Opie

Broch-Hoell, Nils: The Pentecostal Movement: Its Origin, Development, and Distinctive Character ...................... Timothy L. Smith

Coughlin, Bernard J.: Church and State in Social Welfare .. Robert T. Handy Minutes of the Council and Society 